\title{
LEGISLATIVE DELEGATION, THE UNITARY EXECUTIVE, AND THE LEGITIMACY OF THE ADMINISTRATIVE STATE
}

\author{
PETER M. SHANE*
}

Federalist Society constitutionalists frequently launch two critiques of the modern administrative state. One, the nondelegation critique, challenges the now-customary breadth of legislative delegation to the executive branch. ${ }^{1}$ The other, the unitary executive theory, challenges congressional attempts to diffuse executive branch policymaking power at levels below the President. ${ }^{2}$ The Emergency Economic Stabilization Act of $2008^{3}$ is a dramatic target for the first critique. Agencies whose heads are insulated from direct presidential policy control, like the Federal Trade Commission (FTC), ${ }^{4}$ are clear targets for the second.

If we focus separately on the government design variables at the heart of each of these critiques, one can imagine four different ways, shown in the table below, in which those variables might shape the administrative state. One axis of the table describes two contending positions on Congress's capacity to structure the allocation of power within the executive branch. That authority could be broad, encompassing significant congressional power to decide who gets to determine matters of administrative policy. Or, following unitary executive theory, Congress's power could be narrow; once Congress vests policymaking discretion in the executive branch, the President

\footnotetext{
* Jacob E. Davis and Jacob E. Davis II Chair in Law, Moritz College of Law, The Ohio State University.

1. See, e.g., Gary Lawson, The Rise and Rise of the Administrative State, 107 HARV. L. REV. 1231, 1232 (1994).

2. See, e.g., Steven G. Calabresi, Some Normative Arguments for the Unitary Executive, 48 ARK. L. REV. 23 (1995).

3. Pub. L. No. 110-343, 122 Stat. 3765 (2008).

4. See 15 U.S.C. $\S 41$ (2006) (establishing the Federal Trade Commission as an independent agency).
} 
has plenary power to command that discretion no matter where Congress formally conferred it. The other axis of the table is Congress's capacity to delegate policymaking power to the executive in the first place. At one pole is current doctrine, under which there is virtually no enforceable limit on legislative delegation. At the other is the strictly policed nondelegation position that Professor Gary Lawson advocates. ${ }^{5}$

\section{Alternative Structural Design Principles for the}

Administrative State

\begin{tabular}{|c|c|c|c|}
\hline & \multicolumn{2}{|c|}{$\begin{array}{l}\text { Congress's Capacity to Structure the Allocation of } \\
\text { Executive Branch Policymaking Authority }\end{array}$} \\
\hline & & $\begin{array}{c}\text { Narrow } \\
\text { (Unitary Executive } \\
\text { Theory) } \\
\end{array}$ & Broad \\
\hline \multirow{2}{*}{$\begin{array}{l}\text { Scope of } \\
\text { Permissible } \\
\text { Congressional } \\
\text { Delegation of } \\
\text { Policymaking } \\
\text { Authority to the } \\
\text { Executive Branch }\end{array}$} & Narrow & $\begin{array}{l}\text { The Lawson-Calabresi } \\
\text { Vision of Public Law }\end{array}$ & $\begin{array}{l}\text { A combination with no } \\
\text { serious advocates }\end{array}$ \\
\hline & Broad & Scalia Land & $\begin{array}{l}\text { Current constitutional } \\
\text { doctrine regarding the } \\
\text { administrative state }\end{array}$ \\
\hline
\end{tabular}

The current administrative state shows up in this matrix as the state in which Congress has considerable discretion to structure the exercise of administrative power and virtually unlimited discretion to delegate power to the executive. A world in which Congress's authority over the unitary executive is limited and in which there is a more strictly policed nondelegation doctrine describes the constitutional vision of Professors Lawson and Steven Calabresi. ${ }^{6}$ For present purposes, ignore the permutation with a strictly policed nondelegation doctrine but broad congressional discretion to divide up power in the executive branch. If the policymaking discre-

5. See Gary Lawson, Delegation and Original Meaning, 88 VA. L. REv. 327, 376-77 (2002) ("The line between legislative and executive power (or between legislative and judicial power) must be drawn in the context of each particular statutory scheme. In every case, Congress must make the central, fundamental decisions, but Congress can leave ancillary matters to the President or the courts.").

6. Id.; Calabresi, supra note 2, at 103 ("[A] strongly unitary executive is normatively appealing ...."). 
tion of the executive were seriously reduced, Congress might care less about the allocation of intrabranch decision making authority. The final permutation, call it "Scalia Land," is addressed below.

The current administrative state combines wide congressional discretion to delegate regulatory power with considerable discretion to diffuse power throughout the executive branch. Professors Lawson and Calabresi would put us, as it were, in the opposite corner, and Professor Calabresi's frequent collaborator, Professor Saikrishna Prakash, has linked these two elements in his theorizing. ${ }^{7}$ That is, Prakash offers an implicit defense of the unitary executive against imperial presidency charges by pointing out that the policy power of the unitary executive is really subject to Congress's control. ${ }^{8}$ It logically follows that because the President's domestic powers depend almost entirely on the authorities Congress chooses to give him, Congress can forestall presidential imperialism simply by legislating with a tighter hand.

There is something normatively attractive about the Calabresi-Lawson vision. If delegations were narrow, following Professor Lawson's version of the delegation doctrine, ${ }^{9}$ the risk of overconcentration of power in the hands of one man or woman could well diminish. The problem is that Professor Lawson's vision will never be implemented. The idea of a vigorous legislative nondelegation doctrine is a bipartisan nonstarter. The Supreme Court has given up on the enforcement of a robust nondelegation doctrine. ${ }^{10}$ This conclusion is as true for Justice Scalia as for any other individual on the Court. ${ }^{11}$ The nondelegation doctrine is even less likely to reas-

7. See Saikrishna B. Prakash, Fragmented Features of the Constitution's Unitary Executive, 45 WILlAMETTE L. REV. 701, 772 ("Congress creates the laws that executive officers enforce, thereby constraining the discretion of executive officers. These constraints on the unitary nature of the executive branch make Congress something of a second master over the executive branch.").

8. See id.

9. See Lawson, supra note 5, at 334.

10. See, e.g., Whitman v. Am. Trucking Ass'ns, 531 U.S. 457, 474 (2001) (explaining that "[i]n the history of the Court we have found the ... 'intelligible principle' [needed to avoid a violation of the nondelegation doctrine] lacking in only two statutes," and holding that, in the present case, "the scope of discretion [the section in question] allows is in fact well within the outer limits of our nondelegation precedents").

11. See id. at 462 (majority opinion written by Justice Scalia). 
sert itself now when the economy is weak and the country is looking for a vigorous executive branch response to pressing national problems.

The only significant recalibration of the administrative state that is politically plausible-chiefly because of the ascent of Chief Justice Roberts and Justice Alito-is moving the administrative state towards Scalia Land. Scalia Land maps a world in which Congress delegates very broadly but can do little to insulate any part of the bureaucracy from direct presidential command. ${ }^{12}$ This is a recipe for constitutional disaster.

Organizers of the 2009 Federalist Society National Student Symposium asked members of the panel on "The Administrative State and the Constitution" to consider whether the administrative state might be legitimated by some alternative to originalism as a mode of constitutional interpretation. But a different and more fruitful way of asking this question is: How should we actually conceptualize faithful originalist interpretation with regard to the design of the administrative state?

Scholars in the Federalist Society tend to favor a highly formalistic style of originalism that asks to what degree the precise language of the document, as it would have been understood when adopted, commands or forecloses our current institutional arrangements. ${ }^{13}$ This methodology is difficult to apply persuasively to questions of administrative design.

12. See, e.g., Freytag v. Comm'r of Internal Revenue, 501 U.S. 868, 906 (1991) (Scalia, J., concurring in part and concurring in the judgment) ("[I]t was not enough simply to repose the power to execute the laws (or to appoint) in the President; it was also necessary to provide him with the means to resist legislative encroachment on that power.").

13. See, e.g., Stephen G. Calabresi \& Saikrishna B. Prakash, The President's Power to Execute the Laws, 104 YALE L.J. 541, 550-51 (1994) ("First and foremost, in interpreting text, commonsensically enough, one ought to begin with the text.... Second, though it is true that originalists have in the past made arguments based exclusively on history, they were forced to do so because the textual provisions that they were scrutinizing were more open ended than are the provisions relevant to the unitary Executive debate. Thus, when prior originalist scholarship has looked to history, it has always done so in a manner consistent with the primacy of the law of the text. ... Finally, even after having demonstrated a textual ambiguity, no originalist should rely exclusively upon the Constitution's postenactment 'legislative' history, which is, after all, the history that is least likely to reflect the original understanding. It is better to examine exhaustively the preratification material first and only look at the post-ratification material if it is absolutely necessary to do."); Gary Lawson, Delegation and Original Meaning, 88 VA. L. REV. 327, 398 (2002) ("Originalist analysis, at least as practiced by most contempo- 
In key respects, innovations such as FTC rulemaking would have surprised the Framers. But the ideas of the founding generation about government organization were so tentative, diverse, and experimental that it is almost impossible to see either their contemporary practice or their textual understanding of the Article II Vesting Clause as excluding either policyladen administrative rulemaking or independent agencies. ${ }^{14}$ It takes a lot of evidentiary cherry picking to muster any sort of originalist case for the unitary executive.

A more salient originalist question regarding the legitimacy of modern rulemaking, and many other aspects of the administrative state, is: What values does the Constitution actually entrench, and are modern arrangements a vindication of or an abandonment of those values? After all, the constitutional value of promoting the common defense keeps us from reading the textual prescription of an army and navy as ruling out an air force. Might there not be constitutional values that support broad delegations and independent agencies? The questions we should ask are: What are the constitutional values relevant to an assessment of the administrative state? On what theory of government legitimacy does the Constitution as a whole actually rest?

The theory of legitimacy embodied in the Constitutionespecially if we take its amendments into account-depends on a combination of two things: the degree to which the government is genuinely democratic, specifically the degree to which it pursues a robust vision of both political freedom and political equality, and the degree to which the government is actually effective and competent to address national needs. If the transfer of regulatory authority to the executive subverts democracy or undermines the competence of the national government, then it is sensible to question whether broad delegations are legitimate given our foundational constitutional values. If broad delegations advance democracy and enhance

rary originalists, is not a search for concrete historical understandings held by specific persons. Rather, it is a hypothetical inquiry that asks how a fully informed public audience, knowing all that there is to know about the Constitution and the surrounding world, would understand a particular provision. Actual historical understandings are of course relevant to that inquiry, but they do not conclude or define the inquiry - nor are they even necessarily the best available evidence.").

14. See Peter M. Shane, Madison's Nightmare: How Executive Power THREATENS AMERICAN DEMOCRACY 37-40 (2009). 
government competence, however, there is no good reason to hold them unconstitutional, even though many such delegations may turn out to be bad ideas.

These conditions for legitimate delegation seem to hold. By strengthening accountability both to the public and to the rule of law, broad delegations to the executive branch can enhance democracy and government capacity and thus reinforce the constitutional order. The essence of accountability lies in the transparency of government actions, the public's capacity to insist on justifications for the exercise of power, and arrangements that subject officials to discipline when justifications for their actions fall short. A strong administrative state like the current one can serve these ends. Executive branch policymaking is routinely accompanied by structured, meaningful opportunities for public input and by an intensity of judicial review that is far more scrupulous than judicial review of legislative branch policymaking. Executive branch policymaking is also subject to close legislative oversight and to legal requirements for openness that go beyond anything current laws demand of Congress. ${ }^{15}$

Moreover, the executive branch is most likely to respect democratic norms when there is some protection of senior policymakers from direct presidential command. Using the tools of positive political theory, Professor Matthew Stephenson has shown that "a moderate degree of bureaucratic insulation [from political control] alleviates rather than exacerbates the countermajoritarian problems inherent in bureaucratic policymaking." 16 He sums up the argument as follows:

[A]n elected politician, though responsive to majoritarian preferences, will almost always deviate from the majority in

15. See, e.g., Government Performance and Results Act of 1993, 5 U.S.C. $\$ 306$ (2006) (requiring executive agencies to consult with Congress on strategic planning and to report annually to Congress on performance plans, goals, and results); Freedom of Information Act, 5 U.S.C. $\$ 552$ (2006) (mandating the disclosure of public records by executive branch agencies, but not by the legislative branch); Reports Consolidation Act of 2000, 31 U.S.C. $\$ 3516(d)$ (2006) (instructing inspectors general to report to Congress concerning the most serious management and performance problems for their agencies as well as progress in solving those problems); Legislative Reorganization Act of 1946, Pub. L. No. 79-601, 60 Stat. 812 (1946) (enhancing the oversight powers of the Comptroller General and General Accounting Office).

16. Matthew C. Stephenson, Optimal Political Control of the Bureaucracy, 107 MICH. L. REV. 53, 55 (2008). 
one direction or the other.... [Therefore,] even if the average policy position of presidential administrations tends to track the policy views of the median voter in the electorate, the average divergence between the preferences of the median voter and the president is generally greater than zero. Forcing the politically responsive president to share power with a partially insulated, politically unresponsive bureaucracy tends to reduce the variance in policy outcomes, because bureaucratic insulation creates a kind of compensatory inertia that mutes the significance of variation in the president's policy preferences. Up to a point, the benefit to a majority of voters from a reduction in outcome variance outweighs the cost associated with biasing the expected outcome away from the median voter's ideal outcome. ${ }^{17}$

In other words, democracy is well served by a bureaucracy with broad policymaking discretion and some room for quasiindependent policy judgment at subordinate levels.

What threatens this picture of a democracy-enhancing executive branch-what most jeopardizes its potential ethos of strong public accountability - is not broad delegation but the philosophy of presidentialism. Presidentialism is the idea that the President has a wide range of powers virtually exempt from congressional regulation or judicial review, including the power of command over all discretionary policymaking of other executive officers. As I have argued elsewhere and at some length, ${ }^{18}$ operationalizing unitary executive theory threatens to create an organizational culture of entitlement in the executive branch that is antagonistic to democracy and the rule of law. It helps support an organizational psychology that produces shallow, defensive, ideologically driven, and sometimes lawless decision making. ${ }^{19}$

If I am right, then Scalia Land would be the worst combination of the two structural variables at issue in the administrative legitimacy debate. It would seriously limit Congress's powers to structure accountability within the executive branch, while allowing Congress to give the executive branch a virtually unlimited domain within which to operate without accountability.

17. Id. (emphasis omitted).

18. See SHANE, supra note 14.

19. Id. 
As Professor Edward Rubin has suggested, one should regard nondelegation agitation as a form of "nostalgic desire for the days when elected officials were the primary governmental actors and administrative agencies were nascent or, even better, nonexistent." ${ }^{20}$ This desire is unrealistic and, given modern needs, a largely irrational goal. It expresses a yearning for "a world that we have lost, and that we would be both unable and unwilling to retain." 21

My worry, however, goes beyond this. Nondelegation agitation is a dangerous distraction from the real threat to legitimacy in our time. A truly unitary executive would be less democratically responsive than an executive branch more pluralistic in its operation, but it would be no more competent. The legitimacy of the state is thus vulnerable not because Congress assigns significant policymaking power to the executive branch, but because of efforts by Presidents and misguided Justices to insulate the executive from the checks and balances that the Constitution intends and on which good governance rests.

20. Edward Rubin, The Myth of Accountability and the Anti-Administrative Impulse, 103 MiCH. L. REV. 2073, 2097 (2005).

21. Id. at 2119. 
Copyright of Harvard Journal of Law \& Public Policy is the property of Harvard Law School Journals and its content may not be copied or emailed to multiple sites or posted to a listserv without the copyright holder's express written permission. However, users may print, download, or email articles for individual use. 